\title{
SWOT Analysis of Digital Learning Resources Development in The Department of Sociology Education, Faculty of Social Sciences, Yogyakarta State University
}

\author{
Poerwanti Hadi Pratiwi $^{1}$, Aris Martiana ${ }^{2}$, Datu Jatmiko ${ }^{3}$, Sasiana Gilar Apriantika ${ }^{4}$ \\ 1,2,3,4 Department of Sociology Education, Faculty of Social Sciences, \\ Yogyakarta State University, Indonesia \\ ph_pratiwi@uny.ac.id ${ }^{1}$, aris_martiana@uny.ac.id ${ }^{2}$,jatmikodatu@uny.ac.id ${ }^{3}$, sasiana_gilar@uny.ac.id ${ }^{4}$
}

\begin{abstract}
This study aims to analyze the strengths, opportunities, weaknesses, and threats in the development of digital learning resources in the Department of Sociology Education, Faculty of Social Sciences, Yogyakarta State University, Indonesia. This study uses qualitative methods. SWOT analysis was conducted on several research informants, consisting of 26 students and 7 lecturers in the Department of Sociology Education, Faculty of Social Sciences, Yogyakarta State University. Research data were collected using an open questionnaire accessed via Google Form. Thematic analysis method was used to analyze and evaluate data. Subsequent research findings are compiled based on themes that have been established from four categories, namely strengths, opportunities, weaknesses, and threats in the development of digital learning resources in the Department of Sociology Education, Faculty of Social Sciences, Yogyakarta State University.
\end{abstract}

Keywords: SWOT analysis, digital learning resources, higher education

\section{Introduction}

The development and advancement of technology has brought a great impact on human life. In the current era, humans seem inseparable from technology. One of the said impact is the progress in the field of education. Progress in this field includes computerization and digitalization. One of the digitalization in the field of education is learning with the use of digital learning resources in higher learning institutions. Universities as agents of change should be the main pioneers in the use of digital learning resources. The demand for digital learning resources is inevitable in the Industrial Revolution 4.0. In this all-digital era, it is possible to transform interactions from face-to-face to virtual (synchronous) interactions. There are many benefits that can be obtained from learning with digital learning resources. These benefits include easily accessible anywhere and anytime, cheap, time efficient and many others. The academic community is certainly familiar with digital learning resources and many use them in their learning, including at Yogyakarta State University (UNY).

The use of Digital Learning Resources (SBD) in the Department of Sociology Education at UNY through Be-Smart includes: e-books, e-journals, articles, videos, Youtube, and links (websites)[1]. The type or variety of learning activities used are: delivery of lecture material, discussions, individual assignments, group assignments, quizzes, and examinations. Constraints/obstacles in learning using UNY Be-Smart include two aspects, namely technical 
and substantial, including: network constraints, down server, unattractive menu display, teacher competence, unclear materials, and unelaborate materials. While the advantages are: flexibility (time and place), time effectiveness, and systematic order of materials.

The quality of online learning in the law sociology course using Be-Smart in terms of achieving results is good but non-optimal in terms of technical implementation. The quality of learning can be seen from several aspects, namely: lecturer competence, the delivered material, the learning methods and media used, and the assessment system. The influence of the use of digital learning resources on the learning quality of Legal Sociology course is an increase in the quality of learning in the Law Sociology course, Semester IV of Academic Year 2018/2019 Class A in the Sociology Education Study Program of Faculty of Social Sciences (FIS), UNY can be increased through the use of SBD (Digital Learning Resources), especially using UNY Be-Smart. The use of digital learning resource and can also increase the average grade of student assignments [2].

Based on the results of the previous studies, this research seeks to analyze the strengths, weaknesses, opportunities and challenges faced in developing digital learning resources in the Department of Sociology Education, Faculty of Social Sciences, Yogyakarta State University.

\section{Method}

\subsection{Research type}

This research is a qualitative research aimed to identify, describe, and infer the strengths, weaknesses, opportunities and threats in developing digital learning resources in the Department of Sociology Education, FIS UNY. Qualitative research is used to explore human subjective experiences using non-statistical analysis methods [3]. This is related to the naturalistic inquiry that explores complex human experiences.

This approach directly studies the nature of the relationship between researchers and informants. Qualitative approach means that the data collected is in accordance with the facts in the field, utilizing existing theories as explanatory material. The data are not in the form of numbers, but comes from interview texts, field notes, personal documents, memo notes, and other official documents and is described in narrative form. The research approach used in this study is a qualitative approach. Focusing on solving the right problems regarding strengths, weaknesses, opportunities and threats regarding the development of digital learning resources in the Department of Sociology Education, Faculty of Social Sciences, Yogyakarta State University.

\subsection{Participants}

The informant selection technique is done by purposive sampling. The research informants consisted of 26 students and 7 lecturers from the Department of Sociology Education, Faculty of Social Sciences, Yogyakarta State University. The informants were chosen because they can provide accurate information so that the obtained data from various aspects are in accordance with needs. The researcher chooses informants from lecturers and students because they use digital learning resources in their learning. 


\subsection{Instrument}

Research data were collected using an open questionnaire accessed via Google Form. The main questions consist of four parts within the SWOT Analysis framework, namely strengths, opportunities, weaknesses, and threats in the development of digital learning resources in the Department of Sociology Education, Faculty of Social Sciences, Yogyakarta State University.

\subsection{Data Analysis}

Thematic analysis methods are used to analyze and evaluate data. Thematic analysis emphasizes the process of determining, examining, and recording patterns (or "themes") in data [4]. Themes are patterns throughout the data set that are important for describing phenomena and relating them to specific research questions, and subsequently, themes become categories for analysis. Thematic analysis is carried out through a coding process in six phases to create an established and meaningful pattern. This phase is: familiarization with data, producing initial code, finding themes between codes, reviewing themes, defining and naming themes, and producing final reports [4]. Subsequent research findings are compiled based on themes that have been established from four categories, namely strengths, opportunities, weaknesses, and threats in the development of digital learning resources in the Department of Sociology Education, Faculty of Social Sciences, Yogyakarta State University.

\section{Results And Discussion}

Based on the results of the analysis using the thematic method, four main themes were found regarding the development of digital learning resources in the Department of Sociology Education, Faculty of Social Sciences, Yogyakarta State University, namely: strengths, opportunities, weaknesses, and threats, as shown in Table 1.

Table 1. Students and Lecturers' Opinions about the Development of Digital Learning Resources Based on SWOT Analysis

\begin{tabular}{|c|c|}
\hline \multicolumn{2}{|c|}{ Theme 1: Strengths in the Development of Digital Learning Resources } \\
\hline Lecturers & Students \\
\hline $\begin{array}{l}\text { a. Can be done anywhere as long as the } \\
\text { facilities are adequate }\end{array}$ & $\begin{array}{ll}\text { a. } & N \\
\text { b. } & A\end{array}$ \\
\hline $\begin{array}{l}\text { b. Learning documents can also be accessed } \\
\text { more easily }\end{array}$ & $\begin{array}{l}\text { igh various means and } \\
\text { time and place }\end{array}$ \\
\hline lexible, effective and efficient & d. More practical and easy and in accordance \\
\hline tudents to & \\
\hline & its, paperless and \\
\hline e. $\mathrm{N}$ & \\
\hline material can be easier and & \\
\hline interecting for the curront oromotion & $\begin{array}{l}\text { record the student activities through } \\
1 \text { traces (for example in discussions) }\end{array}$ \\
\hline $\begin{array}{l}\text { h. Can keep up with the development of } \\
\text { technology in the learning process }\end{array}$ & iations are given $\mathrm{fc}$ \\
\hline $\begin{array}{l}\text { i. Provision of the Be-Smart website or } \\
\text { platform for lecturers by the University }\end{array}$ & $\begin{array}{l}\text { i. Possible to recapitulate assignments } \\
\text { submitted by students directly }\end{array}$ \\
\hline j. Internet subsidies policy for students & j. Managing any activities that must be done \\
\hline
\end{tabular}




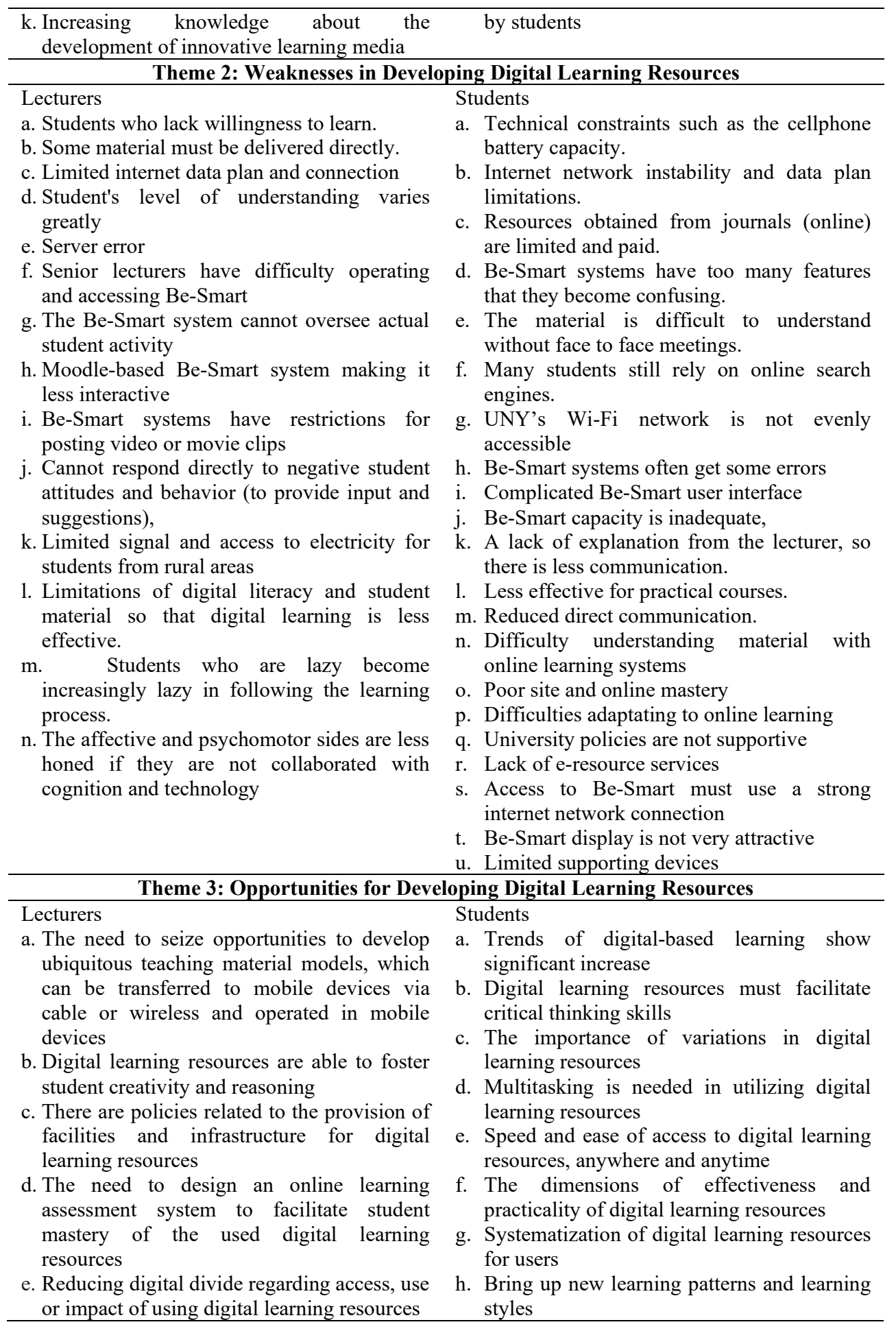


i. Stakeholder policies for providing digital learning resources

j. Availability of a well-integrated LMS (Learning Management System)

\begin{tabular}{|c|c|}
\hline \multicolumn{2}{|c|}{ Theme 4: Threats in Developing Digital Learning Resources } \\
\hline Students & Lecturers \\
\hline a. Equipment used by students in e-learning & a. Equal distribution of infrastructure \\
\hline $\begin{array}{l}\text { b. Network connection in each student's area of } \\
\text { access }\end{array}$ & $\begin{array}{l}\text { b. E-learning practices which include } \\
\text { transferring grades }\end{array}$ \\
\hline $\begin{array}{l}\text { c. The ability of students to understand the } \\
\text { material }\end{array}$ & $\begin{array}{l}\text { c. Student competencies are more specific and } \\
\text { focused in their scientific fields }\end{array}$ \\
\hline d.User identity will be more easily spread & d. Online based learning assessment \\
\hline e. Quality of teachers in mastering e-learning & e. All-digital learning \\
\hline f. Attitude assessment & f. Increasing technological skills and creativity \\
\hline g.Boredom in students & in making e-learning materials \\
\hline h.High creativity is needed & \\
\hline
\end{tabular}

Based on the results of the SWOT analysis in Table 1 above, some things that need to be further discussed related to strengths, opportunities, weaknesses, and threats in developing digital learning resources in the Department of Sociology Education, Faculty of Social Sciences, Yogyakarta State University are as follows.

\section{Theme 1: Strengths in the Development of Digital Learning Resources}

Development of digital learning resources is always in accordance with the use of technology and information within it. There is a lot of strength in developing digital learning resources. These strengths include that the use of digital learning resources is thought to be easier, cheaper, flexible, accessible, practical, effective and efficient than the use of nondigital learning resources. This is backed-up by the answers given by the informants about the advantages of the use of digital learning resources. This is in accordance with the statement, "Basically, computer and network technology media were applied to learning situations, including synchronous and asynchronous network learning, to break through the restrictions on time, location, and schedule, and to achieve the learner-centered individualized learning" [5]. With this technology, learning using digital learning resources can be done anywhere, anytime and by anyone as long as they have the technology and are connected to one another.

Another strength according to lecturers and students is that it is easy to find journals or references to enrich their knowledge in the form of e-libraries and e-resources without having to actually visit the places. Policies issued by the government, universities and related stakeholders support and are relevant in the use of digital learning resources. These policies include the addition and strengthening of infrastructure facilities such as internet networks, signals and the creation of digital learning platforms such as Be-Smart, owned by Yogyakarta State University. Even the university facilitates training for lecturers to learn to make material in accordance with the courses they taught. Improving the quality of human resources in the use of digital learning resources is something that is absolute and important as one of the forces in entering the Industrial Revolution 4.0 [6]. Industrial systems in the future are collaborations of various abilities including technology and human resources.

\section{Theme 2: Weaknesses in Developing Digital Learning Resources}

Weaknesses in developing digital learning resources emphasize the limitations and shortcomings that come from lecturers and students in the online learning process. The focus of thwe weakness theme is the aspects which need improvement and can be avoided in order to achieve the goal of developing effective and efficient digital learning resources. For 
example, unstable connections, limited internet data plan, servers with frequent errors, and limited media literacy, which making it difficult to operate several online learning resource media such as Be-Smart. The use of digital learning resources is not only limited to integrating material into online learning media, but also it must be designed to be easily understood. The next weakness is regarding material that is difficult to convey with online media, especially those related to practical material. Afterall, online learning cannot completely replace learning done directly in the classroom [5]. In addition, the weakness in developing digital learning resources felt by students is the lack of collaboration between images, sound and other media in the delivery of material to further facilitate student understanding.

\section{Theme 3: Opportunities for Developing Digital Learning Resources}

The development of digital learning resources in the learning process in higher education has opportunities that need to be followed up by the stakeholders [7]. The results of the study indicated that the opportunities that enable the development of digital learning resources are ensuring the availability of quality digital learning resources, as well as constantly innovating in the management of digital learning resources through LMS (Learning Management System) owned by the university. In addition, opportunities that need to be followed up are how to plan for students to have new learning experiences through a variety of digital learning resources. This is also an important finding in research conducted [8], that the involvement of students in determining digital learning resources that are relevant and in accordance with the needs of students is an important point that must be planned.

\section{Theme 4: Challenges in Developing Digital Learning Resources}

Digital learning resources will always continue to develop along with the changes that occur in society. The development of digital learning resources is needed to create learning that is fun and able to convey the essence of learning eloquently. The development of digital learning resources in this research has challenges that must be faced so that internet-based learning will have better quality to continue to foster a spirit of learning for students to learn. The development of science and technology, especially the use of technology in the new era, greatly influenced the world of education in general and learning in particular [9]. Humans with new needs, become a big challenge in the world of education in making new innovations that are different from traditional approaches.

Seeing the challenges in developing digital resources, the hard work put to be able to realize internet-based learning with advanced technology that is quality and effective must be a priority. Because digital technology will continue to color various fields in which one of them is education [8]. The challenges faced by students and lecturers are related to different aspects of devices and internet network access, in which all of those equipment and skills are crucial for the smooth running of digital learning. The rapidly developing sciences and technology that have led to innovations in the world also demand the society to keep up with the needed knowledge and skills that require creativity to be able to overcome boredom in learning. The variety of learning resources also have to be kept interesting, so that we need quality teachers to master and conquer this challenge. Regarding learning, certainly an evaluation is needed in the process of determining the final outcome of said learning as what is usually done in conventional learning. In e-learning as well, the cognitive measurement assessment regarding material mastery can be done in various ways. However, attitude assessment is still a challenge needed to be solved.

Based on the explanation above, some recommendations that can be given based on this study are: 


\section{Suggestions for strengthening learning material}

a. Integration of learning materials related to physical skills (hardskills) and mental skills (soft skills)

b. Content material should collaborate media, images, sound and data to make it easier for students to understand the learning material

c. Learning materials are not only adapted to learning competencies, but must also be reinforced by meaningful learning materials

Suggestions for improving the quality of learning

a. Learning should apply values by setting examples, building will, and developing students' creativity in the learning process

b. Online learning processes should still pay attention to affection aspects by establishing communication between lecturers and students

c. Designing a learning that will able to explain or deliver material to students on top of giving the needed material and assignments.

d. Students should take advantage of online learning that is not limited by distance and time, by being active in learning activities

Suggestions for managing digital learning resources

a. Utilization of information and communication technology to improve the efficiency and effectiveness of learning

b. Availability of free access to e-resources such as journals and e-books to make it easier to find learning material

c. Repairing facilities and infrastructure such as eduroam networks and LMS Be-Smart.

\section{Conclusions}

The use of digital learning resources in higher-education institutions must be based on needs analysis, one of which is through SWOT analysis. Digital learning resources in the learning process in higher education have a strategic and important position. SWOT analysis provides actual information in terms of strengths, weaknesses, opportunities, and threats for the development of digital learning resources in the learning process at the Department of Sociology Education at FIS UNY. The results of this SWOT analysis can then be used by stakeholders in their efforts to develop e-learning in higher-education institutions.

\section{Acknowledgement}

Support for this publication has been provided by the Faculty of Social Science, Universitas Negeri Yogyakata. The views expressed in this publication do not necessarily reflect the views of the Faculty of Social Science, Universitas Negeri Yogyakarta.

\section{References}

[1] Pratiwi, P.H., Martiana, A., Januarti, N.E. (2018). Pemanfaatan Sumber Belajar Digital dalam Pembelajaran di Perguruan Tinggi. Laporan Penelitian Research Group. Yogyakarta: FIS UNY. 
[2] Martiana, A., Pratiwi, P.H., Januarti, N.E. (2019). Efektivitas Penggunaan Sumber Belajar Digital Untuk Meningkatkan Kualitas Pembelajaran di Prodi Pendidikan Sosiologi FIS UNY. Laporan Penelitian Research Group. Yogyakarta: FIS UNY

[3] Creswell, J. W. (2015). Research design: Pendekatan kualitatif, kuantitatif, dan mixed (5th ed.). Yogyakarta: Pustaka Pelajar

[4] Fereday J, Muir-Cochrane E. (2006). Demonstrating rigor using thematic analysis: a hybrid approach of inductive and deductive coding and theme development. International Journal of Qualitative Methods 5: 1-11

[5] Lin,Ming-Hung, Chen, Huang-Cheng, Liu, Kuang-Sheng. (2017). A Study of the Effects of Digital Learning on Learning Motivation and Learning Outcome. EURASIA Journal of Mathematics Science and Technology Education, 13(7): 3553-3564.

DOI 10.12973/eurasia.2017.00744a

[6] Tvenge, Martinsen. (2018). Integration of Digital Learning in Industry 4.0. Procedia Manufacturing, 23, 261-266.

[7] Henderson, M., Selwyn, N., \& Aston, R. (2017). What works and why? Student perceptions of 'useful' digital technology in university teaching and learning, Studies in Higher Education, 42(8), 1567-1579, DOI: 10.1080/03075079.2015.1007946

[8] Henderson, et al. (2015). Students' everyday engagement with digital technology in university: exploring patterns of use and 'usefulness'. Journal of Higher Education Policy and Management, 37(3), 308-319. DOI: http://dx.doi.org/10.1080/1360080X.2015.1034424

[9] Fullan, M. \& Langworthy, M. (2013). Towards a New End: New Pedagogies for Deep Learning. Washington: Collaborative Impact Seattle. 